\title{
ЕСКРОУ-РАХУНКИ: ОБЛІКОВІ АСПЕКТИ
}

\section{Ковальова Т.В., канд. екон. наук, доцент Харківський національний автомобільно-дорожній університет}

Постановка проблеми. У 2017 році, для оптимізації платежів, з'явився новий фінансово-юридичний інструмент - рахунок умовного зберігання (ескроу-рахунок). Він відкриває нові можливості для бізнесу й заслуговує на увагу, адже не тільки дозволяє здійснювати фінансові операції, а також $є$ гарантією безпеки сторін під час виконання договору. Рахунки умовного зберігання можна віднести до інструментів, які в умовах нестабільно працюючої економіки, можуть зменшити ризикованість господарської діяльності. Облік, який не стоїть осторонь господарської діяльності, знову стикнувся з нововведеннями. Механізм реалізації ескроу-рахунків закріплений безпосередньо Національним банком України у своїх підзаконних актах, однак, облікові аспекти цього інструменту досі майже не розглядались.

Аналіз останніх досліджень та публікацій. Сутність рахунків ескроу, їх запровадження, специфіку та проблеми використання досліджували у своїх працях Дудлів Н.О., Махиня І.М., Згама А.О., Науменкова С.В., Міщенко С., Тіщенко $€$. Перспективи використання цього виду рахунку розглянула Громницька І.Ю. Дубєй В. пояснив переваги використання ескроу-рахунків в нашій країні. Проте облік на рахунках ескроу не був предметом окремої уваги вітчизняних науковців.

Невирішені складові загальної проблеми. У зв'язку із відсутністю до останнього часу відповідної нормативної бази, особливості обліку операцій на ескроу-рахунках не досліджувалися.

Формулювання цілей статі. Подати обгрунтовані пропозиції щодо обліку на рахунках умовного зберігання кожного з учасників за договором екскроу.

Виклад основного матеріалу дослідження. Інструкція про порядок відкриття, використання і закриття рахунків у національній та іноземних валютах визначила появу рахунку умовного зберігання (ескроу): «рахунок умовного зберігання (ескроу)-рахунок, що відкривається банком клієнту на договірній основі для зарахування на рахунок коштів та перерахування їх/видачі коштів готівкою у випадках, передбачених законодавством України, особі (особам), зазначеній (зазначеним) клієнтом (бенефіціару або бенефіціарам), або повернення таких коштів клієнту за настання підстав, передбачених договором [1].

На сьогодні підприємства в залежності від виду рахунку, що відкритий в установі банку, можуть мати грошові кошти за такими видами: грошові кошти 
на поточному рахунку в банку; грошові кошти на вкладному (депозитному) рахунку; грошові кошти на рахунку умовного зберігання (ескроу). За рахунком умовного зберігання (ескроу) виконуються виключно операції: із зарахування банком отриманих від власника рахунку та/або від третіх осіб коштів, які за настання підстав, визначених договором рахунку умовного зберігання (ескроу), перераховуються бенефіціару(ам)/видаються готівкою бенефіціару(ам) у випадках, передбачених законодавством України, або повертаються власнику рахунку відповідно до умов договору рахунку умовного зберігання (ескроу); пов'язані зі зверненням стягнення на майнові права на кошти, що зберігаються на рахунку умовного зберігання (ескроу), або на права вимоги власника рахунку чи бенефіціара(ів) до банку на підставі договору рахунку умовного зберігання (ескроу) (у випадках, установлених статтею 1076 Цивільного кодексу України); зі сплати винагороди банку за послуги, пов'язані 3 обслуговуванням рахунку умовного зберігання (ескроу) та здійсненням операцій за ним, якщо це передбачено договором рахунку умовного зберігання (ескроу) [1].

Отже, конструкція з ескроу розроблена НБУ передбачає безготівкову форму розрахунків, на відміну від закордонної практики, де використовують будь-яке майно або документ. Світовий досвід доводить, що рахунки ескроу знайшли своє місце у процесі здійснення розрахунків та укладення угод, пов'язаних $з$ купівлею-продажем нерухомості, корпоративних прав, сплатою страхових внесків i податків 3 нерухомості [2]. Хоча, $\epsilon$ i противники використання цього інструменту. Деякі автори вважають, використання ескроурахунків у розрахунках за акції на організованому ринку не $є$ доречним з огляду на наявність ефективного й більш простого механізму - розрахунків за принципом «поставка цінних паперів проти оплати» [3].

Дефініція «ескроу» (escrow) прийшла до нас 3 англійської мови, вона означає: «гроші, майно або документ, що знаходяться на збереженні в третьої особи до виконання певної умови»; за іншою версією, це термін старофранцузького походження («еscroue» як «сувій, перелік, список») [4]. Наприклад, якщо двоє друзів уклали парі, то вони можуть передати суму, на яку вони посперечалися, на зберігання третій особі, якій обидва довіряють. Так усі будуть впевнені, що після вирішення суперечки гроші перейдуть до того, хто їх заслужив.

Фактично, цей інструмент $є$ прогресивним кроком до імплементації європейського законодавства в Україні. Однак, реалії використання його в нашій країні виявили, що лише деякі банки наразі можуть запропонувати клієнтам відкриття ескроу рахунку та лише в межах процедури примусового викупу акцій у міноритарних акціонерів особою, яка володіє домінуючим контрольним пакетом акцій [2]. Ми підтримуємо думку Дудлів Н.О. та Махині I.M. [5], що набагато ефективніше використовувати ескроу-рахунки не лише для процедури примусового викупу акцій у міноритарних акціонерів, а й для 
розрахунків з купівлею-продажем нерухомості, корпоративних прав, сплатою страхових внесків і податків 3 нерухомості.

Договір рахунка умовного зберігання є основою для здійсненя операцій на ескроу-рахунках. Даний договір є взаємним, оскільки кожна із сторін має як права, так і обов'язки передбачені самим договором. Учасниками договору є три особи: власник рахунку, ескроу-агент та бенефіціар (табл.1).

Таблиия 1

Учасники ескроу-договору та їх характеристика

\begin{tabular}{|c|c|c|}
\hline Учасники & Права учасників & Обов’язки учасників \\
\hline $\begin{array}{l}\text { власник } \\
\text { рахунку } \\
\text { (депонент) }\end{array}$ & $\begin{array}{l}\text { вимагати від ескроу-агента (банку) надання } \\
\text { інформації чи документів; за умови внесення } \\
\text { грошових коштів на рахунок ескроу та } \\
\text { повернення банком грошових коштів, у } \\
\text { випадках, передбачених } \\
\text { використовувати визначені способи здійснення } \\
\text { грошових операцій }\end{array}$ & $\begin{array}{l}\text { передача грошових кошти } \\
\text { ескроу-агенту }\end{array}$ \\
\hline $\begin{array}{l}\text { ескроу- } \\
\text { агент } \\
\text { (банк) }\end{array}$ & $\begin{array}{l}\text { має право використовувати грошові кошти на } \\
\text { рахунку ескроу й отримувати винагороду за } \\
\text { послуги, пов'язані з об-слуговування рахунку та } \\
\text { здійсненням операцій за ним, якщо інше не } \\
\text { передбачено договором ескроу; має право } \\
\text { відмовити депоненту або бенефіціару в } \\
\text { проведенні } \text { банківських операцій, що } \\
\text { суперечать чинному законодвству й умовам } \\
\text { договору ескроу; відмовити у видачі } \\
\text { депонованої суми бенефіціару, якщо } \\
\text { документи, надані ним, не відповідають умовам } \\
\text { договору ескроу за зовнішніми ознаками чи } \\
\text { іншим вимогам, установленим цим договором; }\end{array}$ & $\begin{array}{l}\text { забезпечення збереження } \\
\text { грошових коштів депонента і } \\
\text { передача їх бенефіціару чи } \\
\text { депоненту відповідно до } \\
\text { умов договору }\end{array}$ \\
\hline бенефіціар & $\begin{array}{l}\text { може отримувати від ескроуагента відомості } \\
\text { або документи, що відображають операції за } \\
\text { договором ескроу; отримати грошові кошти за } \\
\text { підстав, передбачених цим договором; під час } \\
\text { отримування грошових коштів із рахунку } \\
\text { ескроу використовувати визначені способи } \\
\text { здійснення банківських операцій }\end{array}$ & $\begin{array}{l}\text { здійснення певних дії й } \\
\text { надання ескроу-агенту } \\
\text { певних документів, для } \\
\text { отримання від останнього } \\
\text { грошових коштів }\end{array}$ \\
\hline
\end{tabular}

Джерело: сформовано за [3]

Якщо 3 юридичної точки зору оформлення операцій з ексроу-рахунками більш менш урегульоване, то з облікової - не все є зрозумілим. Практикуючим бухгалтерам необхідно постійно опрацьовувати законодавчу базу щодо обліку грошових коштів для правильного і своєчасного облікового відображення їх руху. Наразі ця законодавча база щодо обліку на екскроу-рахунках знаходиться на стадії розвитку і формування, особливо це стосується депонента та беніфіціара. Оперативно на зміну нормативних актів 3 обліку за рахунками умовного зберігання відреагував НБУ, шляхом внесення змін до Плану 
рахунків бухгалтерського обліку банків України, зобов'язавши вести облік ескроу-агенту на пасивному рахунку 2602 «Кошти суб'єктів господарювання за рахунками умовного зберігання (ескроу)» [6]. Крім того, врегульовані також питання про порядок відкриття та закриття рахунків умовного зберігання (ескроу); встановлено перелік документів, який клієнт подає до банку під час відкриття рахунку умовного зберігання (ескроу); визначено виключний перелік операцій, які можна здійснювати за рахунком умовного зберігання (ескроу); надано право нерезидентам-інвесторам відкривати рахунки умовного зберігання (ескроу) для перерахування коштів бенефіціарам, акції яких придбаваються відповідно до вимог статті 65 Закону України «Про акціонерні товариства»; визначено порядок відкриття поточного рахунку типу «Н» представництву донорської організації; звернення стягнення на предмет обтяження, яким $\epsilon$ майнові права на грошові кошти, що знаходяться на банківському рахунку, шляхом договірного списання за платіжною вимогою обтяжувала [7]. Відсутні будь-яких законодавчо врегульованих рекомендацій 3 обліку за екскроу-рахунком у власника рахунку (депонента) дають простір для роздумів бухгалтерам-практикам. Науковці приділяли увагу порядку облікового відображення операцій з грошовими коштами в системі рахунків загалом, не говорячи про рахунки умовного зберігання. Серед науковців, які займались питаннями обліку грошових коштів були: Подолянчук О.А., Григоревська О.О., Дерій М.В., Сахаров П.О. та ін. Кількість рахунків, призначених для групування інформації про об'єкти обліку грошових коштів визначені Планом рахунків [8]. Безумовно, що для обліку грошей на рахунках умовного зберігання, слід залучити рахунок 31 «Рахунки в банках», який призначено для обліку наявності та руху грошових коштів, що знаходяться на рахунках в банку, які можуть бути використані для поточних операцій. У розрізі субрахунку 313 «Інші рахунки в банку в національній валюті» та 314 «Інші рахунки в банку в іноземній валюті» пропонуємо вести облік відповідно до екскроу договору на аналітичних рахунках 313 «Екскроу-рахунок в національній валюті» та 314 «Екскроу-рахунок в іноземній валюті». Відкривати окремий субрахунок до 31 синтетичного рахунку, мабуть, буде не доречним, оскільки, використання цього рахунку не буде масовим. У обліку, операції за цим видом рахунку будуть відображатись наступним чином (табл.2).

Таблиия 2

Облік операцій за екскроу - рахунком у власника рахунку

\begin{tabular}{|l|c|c|}
\hline \multicolumn{1}{|c|}{ Зміст господарської операції } & \multicolumn{1}{|c|}{ Кореспонденція рахунків } \\
\cline { 2 - 3 } & дебет & кредит \\
\hline Перераховано кошти на екскроу-рахунок & 313,314 & 301,302, \\
& & 311,312 \\
\hline Закрито рахунок у разі невикористання коштів & 311,312 & 313,314 \\
\hline $\begin{array}{l}\text { Сплачено банку витрати за відкриття рахунку (світова практика } \\
1 \% \text { від суми) }\end{array}$ & 92 & 711 \\
\hline $\begin{array}{l}\text { Нараховані проценти за користування банком коштами власника } \\
\text { якщо передбачено договором) }\end{array}$ & 311,312 & 685 \\
\hline Нарахована винагорода банку за зберігання коштів & 311,312 & \\
\hline \multicolumn{2}{|c|}{79} & \\
\hline
\end{tabular}


Оскільки, бенефіціар отримає кошти тільки після виконання всіх умов, передбачених у договорі екскроу, відповідно облік цих коштів слід вести на позабалансовому рахунку. Хоча, гроші на цьому рахунку не $\epsilon$ активом бенефіциара, однак обліковувати їх необхідно. Ми пропонуємо доповнити існуючий рахунок 06 «Гарантії та забезпечення отримані» субрахунком 061 «Кошти на екскроу-рахунку». У Інструкцію про застосування Плану рахунків бухгалтерського обліку активів, капіталу, зобов'язань і господарських операцій підприємств і організацій [9] у частині, що характеризує рахунок 06 ми пропонуємо добавити слово «гроші на екскроу-рахунках» і тоді вислів буде таким: «вартість товарно-матеріальних цінностей, основних засобів, цінних паперів та грошей на екскроу-рахунках (які знаходяться як на підприємстві, так і в депозиті нотаріальної контори чи банку), що становлять предмет застави». Особливо актуальним буде використання цього субрахунку при операціях 3 нерухомістю. Як правило, саме транзакції 3 нерухомістю відрізняються комплексною і досить складною для аналізу документацією. А також існує ризик для обох сторін: продавець - ризикує можливістю відмови покупця, а покупець - сплатою авансу або завдатку, повернення якого буде супроводжуватися зайвими витратами для покупця [10].

Висновки 3 проведеного дослідження. За результатами проведеного дослідження обгрунтовано використання рахунків бухгалтерського обліку у кожного учасника договору екскроу. Зокрема, запропоновано кореспонденція рахунків за операціями $з$ екскоу-рахунком у депонента. У бенефіціара гроші, що розміщені на рахунку екскроу, ми пропонуємо відображати на позабалансовому рахунку. Облік у екскроу-агента уже законодавчо врегульовано, при відображенні інформації за цим рахунком слід керуватись Планом рахунків бухгалтерського обліку банків України. Напрямки використання та обліку грошей на екскроу-рахунках суб'єктами господарювання та банками є перспективними та підлягають подальшому вивченню та удосконаленню, зокрема, досліджень потребують питання сплати податків при операціях з ескроу.

\section{Перелік посилань}

1. Інструкція про порядок відкриття, використання і закриття рахунків у національній та іноземних валютах. Постанова Правління НБУ 12 листопада 2003 року № 492: сайт URL: https://zakon.rada.gov.ua/laws/show/z1172-03 (дата звернення: 01.10.2020).

2. Лихачов М., Пиголь О. Ескроу рахунки: міжнародна практика та ii імплементація НБУ: сайт URL: https://yurgazeta.com/publications/practice/neruhomist-ta-budivnictvo/eskrou-rahunkimizhnarodna-praktika-ta-yiyi-implementaciya-nbu.html (дата звернення: 30.09 2020).

3. Гахраманов I., Павловська А. Використання ескроу-рахунка в корпоративних трансакціях: сайт

URL: 
https://uz.ligazakon.ua/ua/magazine_article/EA011142 (дата звернення: 30.09 2020).

4. Згама А. О. Правова природа договору умовного депонування (ескроу): сайт URL: http://lsej.org.ua/1_2018/11.pdf (дата звернення: 15.10 2020).

5. Дудлів Н. О. та Махиня I. М. Запровадження, використання та проблемні аспекти функціонування рахунків ескроу в Україні: сайт URL: http://molodyvcheny.in.ua/files/journal/2018/10/182.pdf (дата звернення: 21.10 2020).

6. Про затвердження Змін до деяких нормативно-правових актів Національного банку України Постанова НБУ від 08.01.2020p. № 1: сайт URL: https://zakon.rada.gov.ua/laws/show/v0001500-20 (дата звернення: 01.10 2020).

7. Про затвердження Змін до деяких нормативно-правових актів Національного банку України: Постанова НБУ від 18.12.2017 р. №133: сайт URL: https://zakon.rada.gov.ua/laws/show/v0133500-17\#Text (дата звернення: $22.102020)$.

8. План рахунків бухгалтерського обліку активів, капіталу, зобов'язань і господарських операцій підприємств і організацій: наказ Міністерства фінансів України від 30.11 .99 p. № 291. : сайт URL: http://zakon2.rada.gov.ua/laws/show/z1557-11 (дата звернення: 26.10.2020).

9. Інструкція про застосування Плану рахунків бухгалтерського обліку активів, капіталу, зобов'язань і господарських операцій підприємств i організацій: наказ Міністерства фінансів України від 30.11.99 р. № 291. : сайт URL: https://zakon.rada.gov.ua/laws/show/z0893-99\#Text (дата звернення: 24.10.2020).

10. Громницька I. Ю. Перспективи використання екскроу-рахунків в Україні: сайт

URL: https://ir.kneu.edu.ua/bitstream/handle/2010/27609/foa_18_1_3.pdf?sequence=1\&is Allowed=y (дата звернення: 30.09 2020).

\section{References}

1.Instruction about the order of opening, use and closing of accounts in national and foreign currencies. Resolution of the NBU Board on November, 12, 2003 № 492 [Instruktsiya pro poryadok vidkryttya, vykorystannya i zakryttya rakhunkiv u natsional'niy ta inozemnykh valyutakh. Postanova Pravlinnya NBU 12 lystopada 2003 roku № 492], available at: https://zakon.rada.gov.ua/laws/show/z1172-03 (last accessed 01.10.2020).

2. Likhachev, M., Pigol, О. Ескроу accounts: international practice and her імплементація of НБУ [Eskrou rakhunky: mizhnarodna praktyka ta yiyi implementatsiya NBU], available at: https://yurgazeta.com/publications/practice/neruhomist-ta-budivnictvo/eskrou-rahunki-

mizhnarodna-praktika-ta-yiyi-implementaciya-nbu.html (last accessed 30.09 2020).

3. Gakhramanov, I., Pavlovska, A. Use of escrow account in corporate transactions [Vykorystannya eskrou-rakhunka $\mathrm{v}$ korporatyvnykh transaktsiyakh], 
available at: https://uz.ligazakon.ua/ua/magazine_article/EA011142 (last accessed 30.09 2020).

4. Zgama, A. O. Legal nature of the conditional deposit agreement (escrow) [Pravova pryroda dohovoru umovnoho deponuvannya (eskrou)], available at: http://lsej.org.ua/1_2018/11.pdf (last accessed 15.10 2020).

5. Dudliv, N. O. and Makhinya, I. M. Introduction, use and problematic aspects of the functioning of escrow accounts in Ukraine [Zaprovadzhennya, vykorystannya ta problemni aspekty funktsionuvannya rakhunkiv eskrou $\mathrm{v}$ Ukrayini], available at: http://molodyvcheny.in.ua/files/journal/2018/10/182.pdf (last accessed 21.10 2020).

6. On approval of Amendments to certain normative legal acts of the National Bank of Ukraine Resolution of the NBU of January 8, 2020 № 1 [Pro zatverdzhennya Zmin do deyakykh normatyvno-pravovykh aktiv Natsional'noho banku Ukrayiny Postanova NBU vid 08.01.2020r. № 1], available at: https://zakon.rada.gov.ua/laws/show/v0001500-20 (last accessed 01.10 2020).

7. On approval of Amendments to certain regulations of the National Bank of Ukraine: Resolution of the NBU of December 18, 2017 №133 [Pro zatverdzhennya Zmin do deyakykh normatyvno-pravovykh aktiv Natsional'noho banku Ukrayiny: Postanova NBU vid 18.12.2017 r. №133], available at: https://zakon.rada.gov.ua/laws/show/v0133500-17\#Text (last accessed 22.10 2020).

8. Chart of accounts for accounting of assets, capital, liabilities and business operations of enterprises and organizations: order of the Ministry of Finance of Ukraine dated 30.11.99 № 291 [Plan rakhunkiv bukhhalters'koho obliku aktyviv, kapitalu, zobov"yazan' i hospodars'kykh operatsiy pidpryyemstv i orhanizatsiy: nakaz Ministerstva finansiv Ukrayiny vid 30.11 .99 r. № 291], available at: http://zakon2.rada.gov.ua/laws/show/z1557-11 (last accessed 26.10.2020).

9. Instructions on the application of the Chart of Accounts for accounting of assets, capital, liabilities and business operations of enterprises and organizations: order of the Ministry of Finance of Ukraine dated 30.11.99 № 291 [Instruktsiya pro zastosuvannya Planu rakhunkiv bukhhalters'koho obliku aktyviv, kapitalu, zobov'yazan' i hospodars'kykh operatsiy pidpryyemstv i orhanizatsiy: nakaz Ministerstva finansiv Ukrayiny vid 30.11 .99 r. № 291], available at: https://zakon.rada.gov.ua/laws/show/z0893-99\#Text (last accessed 24.10.2020).

10. Gromnytska, I. Y. Prospects for the use of extro-accounts in Ukraine: [Perspektyvy vykorystannya ekskrou-rakhunkiv $\mathrm{v}$ Ukrayini], available at: https://ir.kneu.edu.ua/bitstream/handle/2010/27609/foa_18_1_3.pdf?sequence=1\&is Allowed=y (last accessed 30.09 2020).

\section{РЕФЕРАТИ РЕФЕРАТЫ ABSTRACTS}

\section{УДК 336.73:657.2; JEL Classification: M41}

Ковальова Т.В. ЕСКРОУ-РАХУНКИ: ОБЛІКОВІ АСПЕКТИ

Метою дослідження $\epsilon$ висвітлення процесу обліку на рахунках тимчасового зберігання (екскоу-рахунках). Методика дослідження: для досягнення поставленої мети у роботі були використані загальнонаукові i 
спеціальні методи і прийоми дослідження: теоретичного узагальнення, аналізу і синтезу; системного і комплексного підходу; абстрактно-логічний. Через новизну цього інституту для українських банків та підприємств, слід зважено використовувати механізм ескроу-рахунка - на практиці можливі труднощі 3 його використанням, особливо в обліковому аспекті. Результати дослідження: результатом наукової роботи $\epsilon$ теоретичне узагальнення i практичні рекомендації щодо обліку на рахунках-екускору. Бухгалтерський облік операцій з ескроу-рахунків має ряд відмінностей від бухгалтерського обліку операцій зі звичайними банківськими рахунками. Дослідження точок зору науковців дали можливість висловити свою точку зору на це питання $\mathrm{i}$ запропонувати варіанти вирішення проблемних моментів щодо обліку на рахунках-екскроу. Цей вид рахунка $\epsilon$ ефективним механізмом ризикменеджменту і дає змогу досягти балансу інтересів сторін за допомогою організації розрахунків. Наукова новизна: полягає в комплексному дослідженні проблем, пов'язаних 3 обліком на рахунках екскроу. Запропоновано ввести вести облік з використанням аналітичних рахунків та позабалансових, наведена система кореспонденції рахунків у депонента (власника рахунку). Практична значущість полягає в тому, що, за відсутності нормативного врегулювання 3 питань обліку на рахунках екскроу, вказані у роботі пропозиції дадуть змогу практикам покращити стан їх обліку.

Ключові слова: ескроу-рахунок; екскроу; рахунок тимчасового зберігання; облік; рахунок.

\section{УДК 336.73:657.2; JEL Classification: M41}

\section{Ковалева Т.В. ЭСКРОУ-СЧЕТА: АСПЕКТЫ УЧЕТА}

Целью исследования является освещение процесса учета на счетах временного хранения (екскоу-счетах). Методика исследования: для достижения поставленной цели в работе были использованы общенаучные и специальные методы и приемы исследования: теоретического обобщения, анализа и синтеза; системного и комплексного подхода; абстрактнологический. Из-за новизны этого института для украинских банков и предприятий, следует взвешенно использовать механизм эскроу-счета - на практике возможны трудности с его использованием, особенно в учетном аспекте. Результаты исследования: результатом научной работы является теоретическое обобщение и практические рекомендации по учету на счетахекускору. Бухгалтерский учет операций с эскроу-счетов имеет ряд отличий от бухгалтерского учета операций с обычными банковскими счетами. Исследование точек зрения ученых дали возможность высказать свою точку зрения на этот вопрос и предложить варианты решения проблемных моментов относительно учета на счетах-екскроу. Этот вид счета является эффективным механизмом риск-менеджмента и позволяет достичь баланса интересов сторон посредством организации расчетов. Научная новизна: заключается в комплексном исследовании проблем, связанных с учетом на счетах екскроу. Предложено ввести учет с использованием аналитических счетов и 
внебалансовых, приведена система корреспонденции счетов у депонента (владельца счета). Практическая значимость заключается в том, что, при отсутствии нормативного урегулирования по вопросам учета на счетах екскроу, указанные в работе предложения позволят практикам улучшить состояние их учета.

Ключевые слова: эскроу-счет; екскроу; счет временного хранения; учет; счет.

\section{UDC 336.73:657.2; JEL Classification: M41}

Kovalova T.V. ESCROE ACCOUNTS: ACCOUNTING ASPECTS

The aim of the study is to cover the process of accounting for temporary storage accounts (ex-accounts). Methods of research: to achieve this goal in the work were used general and special methods and techniques of research: theoretical generalization, analysis and synthesis; systematic and integrated approach; abstractlogical. Due to the novelty of this institution for Ukrainian banks and enterprises, it is necessary to use the mechanism of escrow account - in practice there may be difficulties with its use, especially in the accounting aspect. Research results: the result of scientific work is a theoretical generalization and practical recommendations for accounting on accounts-ekuskor. Accounting for escrow account transactions has a number of differences from accounting for transactions with regular bank accounts. Researchers' point of view provided an opportunity to express their point of view on this issue and suggest options for solving problematic issues regarding accounting in extra-accounts. This type of account is an effective mechanism of risk management and allows to achieve a balance of interests of the parties through the organization of settlements. Scientific novelty: is a comprehensive study of the problems associated with the accounting of ex-accounts. It is proposed to introduce accounting using analytical and off-balance sheet accounts, the system of correspondence of accounts with the depositor (account holder) is given. The practical significance lies in the fact that, in the absence of regulations on accounting for escrow accounts, the proposals mentioned in the paper will allow practitioners to improve their accounting.

Key words: escrow account; escrow; temporary storage account; accounting; account.

\section{Відомості про авторів / Сведения об авторах / About the Authors}

Ковальова Тетяна Володимирівна - кандидат економічних наук, доцент, Харківський національний автомобільно-дорожній університет, доцент кафедри обліку і оподаткування, м. Харків, Україна; ORCID: https://orcid.org/0000-00031250-2019; e-mail: kovaleva64@ukr.net.

Ковалева Татьяна Владимировна - кандидат экономических наук, доцент, Харьковский национальный автомобильно-дорожный университет, доцент кафедры учета и налогообложения, г. Харьков, Украина.

Kovalova Tetiana Volodimipovna - Candidate of Sciences (Economics), Kharkov National Automobile and Highway University, Associate Professor at the Department of account, taxation, Kharkiv, Ukraine. 